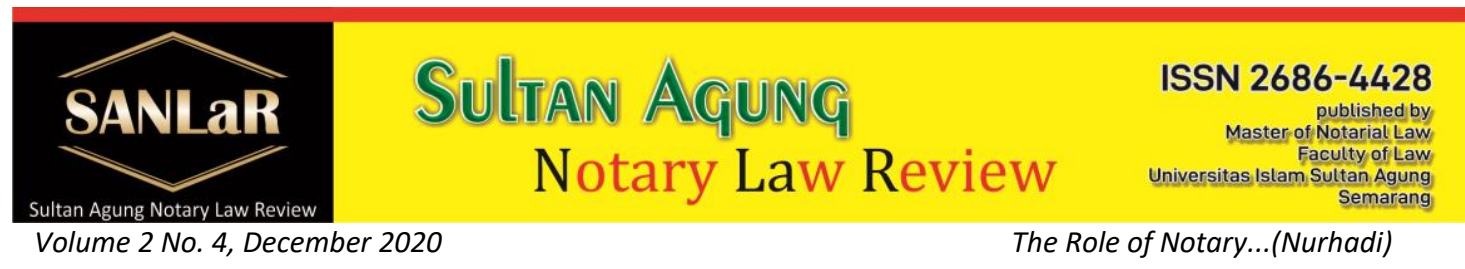

\title{
The Role of Notary Honorary Council after Constitutional Court Decision Number: 16/PUU-XVIII/2020
}

\author{
Nurhadi *) \\ ${ }^{*}$ Student of Master of Notary Law, Faculty of Law, Universitas Islam Sultan Agung \\ Semarang
}

\begin{abstract}
Public complaints against notaries should be the object of review by the supervisory board based on the code of ethics and applicable laws. When the supervisory panel finds an alleged criminal act in the results of its review, it is important to submit it to the Notary Honorary Council for further action. This study uses a sociological juridical approach (empirical) in a qualitative descriptive manner. This research specification focuses on empirical normative studies, namely legal research equipped with empirical data. The data collection method in this study was carried out by field studies and literature studies. The data obtained were then analyzed qualitatively. The conclusion is that based on the provisions which include Article 66 paragraph (1) UUJN, Constitutional Court Decision Number: 16/PUU-XVIII/2020, Permenkumham No.7/2016, Permenkumham No.15/2020 and MoU No. B/1056/V/2006 Number 01/MOU/PPINI/V/2006 concerning Development and Enhancement of Professionalism in the Field of Law Enforcement, the role of the Notary Honorary Council must be put forward in connection with the police report No.: LP288/VII/2020 SPKT Polda Sultra after the Constitutional Court decision Number: 16/PUU-XVIII/2020. Whereas the suggestion is that in order to understand the role of the Notary Honorary Council that must be put forward after the Constitutional Court decision Number: 16/PUU-XVIII/2020, socialization is needed in the wider community so that suspected criminal acts by notary persons are not immediately reported to the police but are resolved first through the inspection mechanism in the supervisory board and the honorary council.
\end{abstract}

Keywords: Role; Honor; Notary; Judgment; Constitution.

\section{Introduction}

The public generally requires the presence of a notary when their need for an authentic deed. Such a noble position of Notary Public must of course be maintained for the sake of public trust in the implementation of the mandate of the position. As a consequence, they must obey and be loyal to the Republic of Indonesia, Pancasila and the 1945 Constitution of the Republic of Indonesia, the Law on the Position of Notary Public and other laws and regulations.

In that capacity, the Notary keeps everything concerning the deed he has drawn and all information obtained for the making of the deed. This condition requires that the notary's behavior be in line with the oath/promise of office. According 
to the provisions of Article 65 of Act No. 30 of 2004 concerning the Position of Notary Public (UUJN) states that a notary is responsible for any deeds he makes even though the Notary protocol has been submitted or transferred to the notary protocol depositor. This also relates to professional ethics. Where professional ethics is applied to certain functional groups to confirm the situation so that the role or function of these groups becomes clear. ${ }^{1}$

Notary as a profession is certainly bound by ethical norms in that professional environment. The existence of this norm is so that the notary occupants do not deviate from their duties and authorities. This requires an institution capable of fostering and supervising Notaries. As a measure to fulfill it, the government through the Ministry of Law and Human Rights issues its regulations. Through this ministry policy, the Republic of Indonesia Minister of Law and Human Rights Regulation Number 7 of 2016 concerning Notary Honorary Council was issued

The authority of the Minister of Law and Human Rights in supervising is obtained by attribution as stipulated in Article 67 paragraph (1) because the person concerned is the minister whose duties and responsibilities cover the notary sector. With this authority, a Notary Honorary Council was formed in accordance with Article 66A paragraph (3) of Act No. 30 of 2004 concerning the Position of Notary Public as amended by Act No. 2 of 2014 concerning Amendments to Act No. 30 of 2004 concerning the Position of Notary Public.

On the basis of maintaining the nobility of the position, the Notary's behavior must be measured according to its proportion. Whereas then there is an allegation that this behavior constitutes a crime, so it should be submitted to the supervisory panel to evaluate it first. The function of the supervisory board is so that all rights and authorities as well as obligations given to Notaries in carrying out their duties as given by the prevailing laws and regulations are always carried out on a predetermined path, not only legal channels, but also on moral and ethical grounds for the sake of ensuring legal protection and legal certainty for those who need it. ${ }^{2}$

Ideally, every notary's behavior in carrying out his duties and authority must be completed within the scope of his profession. Ethical and administrative actions must be put forward when there is a party that feels that the Notary has aggrieved. The ideal role of the Notary Supervisory Board is strategic in maintaining the nobility of the profession. Public complaints against notaries should be the object of review by the supervisory board based on the code of ethics and applicable laws. When the supervisory panel finds an alleged criminal act in the results of its review, it is important to submit it to the Notary Honorary

\footnotetext{
${ }^{1}$ Prakoso, Abintoro. (2015). Etika Profesi Hukum Telaah Historis, Filosofis dan Teoritis Kode Etik Notaris, Advokat, Polisi, Jaksa dan Hakim. Surabaya: Laksbang Justitia. p. 63.

2 T, Donald, H. L. (2020). Legalitas Keberadaan Majelis Pengawas Notaris Dan Majelis pengawas Notaris. Jurnal Penelitian Hukum De Jure, 20 (3). p. 447.
} 
Council for further action. This is based on Article 66 paragraph (1) of Law of the Republic of Indonesia Number 2 of 2014 concerning Amendments to Law Number 30 of 2004 concerning the Position of Notary Public, which states: "For the purposes of the judicial process, investigators, public prosecutors, or judges with the approval of the Notary Council are authorized to: a. take a photocopy of the Minuta Deed and/or letters attached to the Minuta Deed or Notary Protocol in the storage of the Notary; and b. summon the Notary to be present in the examination related to the Notary Deed or Protocol that is in the Notary's custody. "

Criminal cases involving notaries also occurred in Southeast Sulawesi, based only on the allegation that a notary who served in Muna District was reported to the police. The reporter was annoyed with the action that was alleged to have changed the company's deed without involving himself as the President Director as well as the largest shareholder according to the decision of the PT. Graha Raditya Realtor in $2012^{3}$. The reporters' actions based on these allegations are interesting to examine in terms of the role of the notary honor council. The existence of the notary honor council is not visible because the reporter immediately complained the case to the Southeast Sulawesi Regional Police (Polda Sultra) as the evidence of the reporting with police report No. : LP288/VII/2020 SPKT Polda Sultra. Due to this fact, the proposed thesis has the title " The Role of Notary Honorary Council after Constitutional Court Decision Number: 16/PUU-XVIII/2020 (An Overview of Police Report No.: LP288/VII/2020 SPKT Polda Sultra)".

\section{Research Methods}

This study uses a sociological juridical approach (empirical) in a qualitative descriptive manner. This research specification focuses on empirical normative studies, namely legal research equipped with empirical data. The data collection method in this study was carried out by field studies and literature studies. The data obtained were then analyzed qualitatively.

\section{Results and Discussion}

The Role of Notary Honorary Board Regarding Police Report No. : LP288/VII/2020 SPKT Polda Sultra after Constitutional Court Decision Number: 16/PUUXVIII/2020

Police Report Number: LP 288/VII/2020 SPKT Polda Sultra dated 15 July 2020, when there was a change of deed at PT. Graha Raditya Realtor conducted by a Notary in Muna Regency, Yani Kalimudin. Due to the change in the deed, a

\footnotetext{
${ }^{3}$ Suyoto, Abd. Rasyid. (2020). Diduga Palsukan Dokumen, Salah Satu Notaris di Muna Dilapor Polisi. https://detiksultra.com/kriminal/diduga-palsukan-dokumen-salah-satu-notaris-di-munadilapor-polisi/, accessed on February 9, 2021.
} 
person named Wa Ode Uamaya Latief, reported to the Southeast Sulawesi Regional Police (Polda Sultra), because he felt that he was disadvantaged. ${ }^{4}$

Based on the police report Number: LP 288/VII/2020 SPKT Polda Sultra, this will later become part of a series of legal processes starting from investigation, investigation, prosecution to trial. On the other hand, this incident is closely related to the Notary as a profession. So that the object of reporting in the form of forgery and embezzlement of shares should be seated first based on the professional standards of the reported (Notary Yani Kalimudin). The provisions of Article 66 paragraph (1) of Act No. 2 of 2014 concerning Amendments to Act No. 30 of 2004 concerning the Position of Notary (UUJN) itself state that:

"For the purposes of the judicial process, investigators, public prosecutors, or judges with the approval of the Notary Council are authorized to:

1. take a photocopy of the Minuta Deed and/or letters attached to the Minuta Deed or Notary Protocol in the storage of the Notary; and

2. summon the Notary to be present in the examination related to the Notary Deed or Protocol that is in the Notary's custody. "

It was understood later that the Constitutional Court of the Republic of Indonesia issued a decision on case Number: 16/PUU-XVIII/2020 on Tuesday, the twentythird, June, year two thousand and twenty, finished at 11.10 WIB, by nine Constitutional Justices, namely Anwar Usman as Chairman and Member, Aswanto, Wahiduddin Adams, Suhartoyo, Arief Hidayat, Saldi Isra, Daniel Yusmic P. Foekh, Enny Nurbaningsih, and Manahan MP Sitompul, respectively as Members, assisted by Yunita Rhamadani as Substitute Registrar, and attended by the Petitioners, the House of Representatives or those representing and the President or those who represent.

It was discovered later that the verdict of the Constitutional Court with case Number: 16/PUU-XVIII/2020 concerning 2 things, namely:

1. Stating that the petition of Petitioner I, Petitioner III, Petitioner IV, and Petitioner $\mathrm{V}$ cannot be accepted;

2. Rejecting Petitioner II's petition for other than and the rest

Based on the petition of the petitioners and the decision of the panel of constitutional judges as mentioned above, the legal existence of Article 66 paragraph (1) UUJN has not changed at all. This is based on the judge's decision on case Number: 16/PUU-XVIII/2020 which clearly states:

1. Stating that the petition of Petitioner I, Petitioner III, Petitioner IV, and Petitioner $\mathrm{V}$ cannot be accepted;

2. Rejecting Petitioner II's petition for other than and the rest.

Because the petitioners' petition cannot be accepted, the legal existence of Article 66 paragraph (1) of the UUJN remains in the status quo. This is based on the fact that the judge's decision on case Number: 16/PUU-XVIII/2020 has not touched the subject matter. Thus, the entire petition of the petitioners has not

\footnotetext{
${ }^{4}$ Suyoto, Abd. Rasyid. (2020). OpCit, accessed on February 9, 2021.
} 
been granted. Based on the decision of case Number: 16/PUU-XVIII/2020, it becomes clear that the role of the Notary Honorary Council in handling police reports No. : LP288/VII/2020 SPKT Polda Sultra is getting confirmed. This is understood because police report No. : LP288/VII/2020 SPKT Polda Sultra The event took place on July 15, 2020. While the Constitutional Court decision Number: 16/PUU-XVIII/2020 was decided in July 2020.

In line with the decision on the case Number: 16/PUU-XVIII/2020, the further legal process regarding Report No. : LP288/VII/2020 SPKT Polda Sultra, must adhere to Article 66 paragraph (1) UUJN. This means that as long as the police follow up the report until the investigation stage, the summons for Notary Yani Kalimudin must be approved by the Notary Honorary Council. The provisions of Article 1 point 1 of the Regulation of the Minister of Law and Human Rights Number 7 of 2016 concerning the Notary Honorary Council, (Permenkumham No.7/2016) states:

"The Notary Honorary Council is a body that has the authority to carry out Notary guidance and the obligation to give approval or rejection for the purposes of investigation and judicial process, for taking a photocopy of the Minuta Deed and calling the Notary to be present at the examination relating to the Notary Deed or Protocol in storage. Notary Public."

With the understanding of Article 1 number 1 Permenkumham No.7/2016, it can be seen clearly about the authority of the Notary Honorary Council with regard to the implementation of Notary guidance and the obligation to give approval or rejection for the purpose of investigation. If you look at the concept of modern criminal law, it is not true that you retaliate for a criminal act but as a corrective action. ${ }^{5}$

The head of the Southeast Sulawesi Indonesian Notary Association (INI), Sudirman, SH, M.Kn., said that between the Indonesian National Police (Polri) and the Central Executive of the Indonesian Notary Association (PP INI) had already made a Memorandum of Understanding ( MoU) No. B/1056/V/2006 Number 01/MOU/PP-INI/V/2006 concerning the Development and Improvement of Professionalism in the Field of Law Enforcement, which was extended back in 2018 in connection with the issuance of the Law on Notary Position Number 2 of 2014, amendments to the Act No. 30 of 2004 concerning the position of a Notary.

"Based on the decision of the Constitutional Court (Constitutional Court) also when there is a Notary who is questioned by the police, it must be approved by

\footnotetext{
${ }^{5}$ The concept of modern criminal law has indeed left a repressive objective of retaliating for criminal offenses and is more concerned with corrective (for the convicted person) and preventive (for other members of the community). See, Budiono Kusumohamidjojo. (2019). Teori Hukum Dilema Antara Hukum Dan Kekuasaan,Cetakan III. Bandung: Yrama Widya. p.87.
} 
the MKN (Notary Honorary Council). Not in the MPD (Regional Supervisory Council) as before. ${ }^{6}$

Based on the statement by the Chairman of INI Southeast Sulawesi, the role of MKN in the examination of the notary in Muna Regency, Yani Kalimudin, was based on Report No. : LP288/VII/2020 SPKT Polda Sultra, very important. Based on the MoU Polri and PP INI Number. B/1056/V/2006 Number 01/MOU/PPINI/V/2006 in the understanding number 1 states:

"The Parties always respect each other and maintain the independence of each party in carrying out their duties, positions and professions, by always obeying the prevailing laws and regulations."

It is also understood that the MoU is tied to the azaz pacta sunt servanda, so either the Police or the PP INI are related to police report No. : LP288/VII/2020 SPKT Polda Sultra is bound by Article 66 paragraph (1) letter b UUJN. This means that in the examination of the Notary Yani Kalimudin requires MKN approval, because this is the goal of Article 66 paragraph (1) letter b UUJN as befits the law. ${ }^{7}$

Dr. Ma'ruf Akib, SH, M.Hum., M.Kes., M.Kn., An academic from the Faculty of Law, University of Muhammadiyah Kendari, said that ideally the examination should first be carried out through the Regional Supervisory Council (MPD) because of the background of the police report No. . : LP288/VII/2020 SPKT Polda Sultra due to change of deed of PT. Graha Raditya Realtor in 2012. This clearly concerns the alleged violation of notary behavior as referred to in Article 2 of the Regulation of the Minister of Law and Human Rights of the Republic of Indonesia Number 15 of 2020 concerning Procedures for Examination of the Supervisory Board of Notaries (Permenkumham No.15/2020):

"The Supervisory Council has the authority to provide guidance and supervision to Notaries as well as to conduct examinations of suspected violations of behavior and implementation of the Notary's office."

Based on the above, according to Dr. Ma'ruf Akib, SH, M.Hum., M.Kes., M.Kn., It will be known to what extent the violations occurred. "If indeed the result of the MPD examination panel is proven to be a serious violation, then the notary concerned can be proposed to be dishonorably dismissed from his position.

"If the dismissal occurs then the criminal report will no longer require MKN approval. The person concerned is no longer a Notary. Article 66 paragraph (1) letter $b$ of the UUJN applies to an active notary public. "8

\footnotetext{
${ }^{6}$ Interview, Sudirman, SH, M.Kn., Monday February 8, 2021.

${ }^{7}$ Sebagaimana dipahami oleh Nonet dan Selznick, dalam rangka pencapaian tujuan hukum, yang terpenting adalah hasil-hasil substantive serta tanggung jawab yang efektif. Lihat. Dossy Iskandar Prasetyo and Bernard L.Tanya. (2011). Hukum Etika \& Kekuasaan.Yogyakarta: Genta Publishing. p.105.

${ }^{8}$ Interview Dr. Ma'ruf Akib, SH, M.Hum., M.Kes., M.Kn., Tuesday February 9, 2021.
} 
Based on the various things described above based on Article 66 paragraph (1) UUJN, Constitutional Court Decision Number: 16/PUU-XVIII/2020, Permenkumham No.7/2016, Permenkumham No.15/2020 and MoU No. B/1056/V/2006 Number 01/MOU/PP-INI/V/2006 concerning the Development and Improvement of Professionalism in the Field of Law Enforcement, the role of the Notary Honorary Council must be put forward.

\section{Closing}

\subsection{Conclusion}

Based on the provisions covering Article 66 paragraph (1) UUJN, Constitutional Court Decision Number: 16/PUU-XVIII/2020, Permenkumham No.7/2016, Permenkumham No.15/2020 and MoU No. B/1056/V/2006 Number 01/MOU/PPINI/V/2006 concerning Development and Enhancement of Professionalism in the Field of Law Enforcement, the role of the Notary Honorary Council must be put forward in connection with the police report No. : LP288/VII/2020 SPKT Polda Sultra after the Constitutional Court decision Number: 16/PUU-XVIII/2020.

\subsection{Suggestion}

In order for an understanding of the role of the Notary Honorary Council that must be put forward after the decision of the Constitutional Court Number: $16 / \mathrm{PUU}-\mathrm{XVIII} / 2020$, socialization is needed in the wider community so that alleged criminal acts by notary persons are not immediately reported to the police but are resolved first through an examination mechanism in supervisory council and honorary council.

\section{Referencess}

Journal:

T, Donald, H. L. (2020). Legalitas Keberadaan Majelis Pengawas Notaris Dan Majelis pengawas Notaris. Jurnal Penelitian Hukum De Jure, 20(3).

Books:

[1] Budiono Kusumohamidjojo. (2019). Teori Hukum Dilema Antara Hukum Dan Kekuasaan, Cetakan III. Bandung: Yrama Widya.

[2] Dossy Iskandar Prasetyo and Bernard L.Tanya. (2011). Hukum Etika \& Kekuasaan.Yogyakarta: Genta Publishing.

[3] Prakoso, Abintoro. (2015). Etika Profesi Hukum Telaah Historis, Filosofis dan Teoritis Kode Etik Notaris, Advokat, Polisi, Jaksa dan Hakim. Surabaya: Laksbang Justitia. 
Internet:

Suyoto, Abd. Rasyid. (2020). Diduga Palsukan Dokumen, Salah Satu Notaris di Muna Dilapor Polisi. https://detiksultra.com/kriminal/didugapalsukan-dokumen-salah-satu-notaris-di-muna-dilapor-polisi/, accessed on February 9, 2021. 